\title{
THE HISTORY OF ORNAMENTATION DEVELOPMENT IN MUSIC, PRINCIPLES OF ITS FORMATION AND PERFORMANCE STYLE
}

\section{Gunel Bakirova}

Ph.D. Candidate, Baku Music Academy named after U. Hajıbeyli; ORCID: 0000-0001-8536-2139; e-mail: gunnel.bakirova.88@mail.ru

Baku Music Academy, Baku, Azerbaijan

\section{Abstract}

This article deals with the history of the development of ornamentation in keyboard music, the principles of its formation and performance styles. Ornamentation is one of the greatest means of expression in keyboard performance. It has ancient historical roots. In keyboard music, ornamentation was subject to various changes depending on the period. Ornamentation manifests itself in various forms in keyboard music. Thus, ornamentation is not just a means of embellishment. It is considered as the main component in the creation of a work. Embellishments are also essential as an aesthetic factor.

The purpose of this research is to review the principle of the embellishments' historical development, to classify the types of ornamentation in music and to determine the role of embellishments in music. At the same time, the research clarifies the concept of the style of ornamentation in the keyboard music of Western Europe.

The research methodology is based on a comprehensive musical-analytical, theoretical and historical analysis, a synthesis of the Western European and Russian musicologists' scientific literature regarding the subject of ornamentation. The research includes links to articles published with regard to ornamentation in music encyclopedias, and the conclusions have been scientifically substantiated.

The scientific novelty of the research. For the first time in the framework of the musical science of Azerbaijan, the features and principles of the ornamentation performance in Western European keyboard music were studied. The findings of the study can be used for future research.

Conclusions. Ornamentation is important in the keyboard music of Western Europe and acts as its main means of expression. The development of ornamentation in keyboard music is directly related to the art of improvisation. So, embellishments are considered as the main means of expression in the art of improvisation. In keyboard music, ornamentation is not only an embellishment of the melody. Along with the structure of the melody, it also plays an important role in creating the rhythmic structure of the work, the artistic content of the work, and the shape of the texture. Musicologists have considered ornamentation from the point of view of various prisms and classified it in various forms. In the modern period, ornamentation is divided into two groups in the form of embellishments and free ornamentation. 
One of the main features of keyboard music in Western Europe is that it reflects the musical traditions of that period. It should be noted that the ornamentation in keyboard music underwent a period of rapid development in the Baroque era. The main characteristic feature here is the lack of regulation of decorations, its change depending on the school, style of performance. Later the concept of style in ornamentation was lost. Thus, in the classical era, the embellishments were already regulated and a common system of decorations in European keyboard music was adopted.

Keywords: Ornamentation; Baroque; keyboard music; style; piano; ornament; performance

\section{Introduction}

Ornamentum, that is, the ornament is a Latin word that means embellishment. It makes sense to harmoniously complement any subject by man or by society for aesthetic purposes. Decorations are also a carrier of information. Ornamentation is an area of art that is closely related to other types of art. There is no such example of a culture in which decorative art is not applied in the culture of other nations in the world.

Although there is a terminological, general point of view and the same in terms of meaning, ornamentation in music is different from ornaments in other types of art. The diversity of use of different expression means is one of the reasons for such a difference. So, if the expression means of the ornament in the art are colour, marble, stone etc., then expression means of the ornament in music are sounds.

The study of ornaments, which is of great importance in the science of music, is one of the relevant problems. It should be noted that ornamentation has an integral in music culture. Ornamentation existed from the early days of music and has become a factor of its essence. In music, the ornament varies depending on the period, geography, the school of its origin and the style of the composer. An ornament is a living organism. It somewhat difficult to think about music without ornamentation, and embellishments are the main means of its expression.

\section{The purpose of the research}

The main purpose of this research is to clarify the principles of ornamentation, its features and performance in Western-European keyboard music based on scientific and theoretical grounds.

\section{Recent research and publications analysis}

Ornamentation was the subject of interest both of Western-European and Russian researchers and was developed in their scientific works. Thus, ornaments were studied theoretically from different prisms - periods, styles, genres of music. In this regard, the results on ornamentation obtained by different musicologists were used in this research paper. The A. Beyschlag's scientific paper "Ornamentation in music", monographs by G. von Dadelsen, M. Druskin, as well as the "Great Soviet Encyclopedia" are the scientific foundations of the article presented. 


\section{Presentation of the main material}

In music, the art for decorating a melody is called ornamentation, and there are metaphors that have a number of semantic similarities and distinctive features. In music, an ornament is called any specific finish. The decoration of the melody is referred to as the art of ornamentation. And ornamentation is referred to small notes set to the melody. From this point of view, it is considered more appropriate to use the term ornamentation in music.

Before studying the features of ornamentation in keyboard music, it is necessary to review the history of the art of ornamentation in music. In music, ornamentation originates in vocal music. Thus, in European music, the vocal genre was in its heyday, while instrumental genres were still emerging. Therefore, the first musical forms originated from vocal music and subsequently found their reflection in other genres. In this regard, we would like to note that ornamentation is primarily manifested in vocal music.

In music, ornamentation has gone through a long historical period of development. In the study regarding the history of the development of ornamentation in music, A. Beyschlag's book "Ornamentation in music" is of great importance: "The cry, which is the whisper of the first person, is more or less preserved. And, perhaps, early music consisted of such simple sounds" (Beyschlag, 1978, p. 5) the sound preserved here can be regarded as the first form of ornamentation.

Ornamentation in one form or another is closely related to the art of improvisation (Neumann, 1988, p. 72). So, if a decoration is a component of improvisation, then mutual improvisation may consist entirely of an ornament. In other words, it can be considered as a means of expression.

Diminution and colorization also take a special place in the history of ornamentation. Diminution in Latin means diminutio, that is, an abbreviation. In polyphonic music, proportionality is called dividing the length of a note. In Western European polyphonic vocal music, the performing arts of the early middle ages and the Renaissance (madrigal, motet), the technique of diminution as an element of improvisation is widely developed. Also, diminution formed the basis of preludes, toccatas, ricercar and fantasies of ancient introspective genres.

Colouring or "koloireren" in German that is "to colour" was widely used in the $14^{\text {th }}-16^{\text {th }}$ centuries. It is called the technique of melody variation. Colouring was performed by adding auxiliary and transitional notes to the main tone of the sound. If the descant cantus was a decoration of the sound reflected in the firmus, the diminutive focused on the theme and sought to enrich it with melodic moves. Diminution in ornamentation refers to the division of large notes into small sizes. This subject was widespread at the time, although it now only applies to the variation form. In the Middle ages, diminution was considered as the highest form.

In this regard, we can distinguish a brief historical path of ornamentation: the early medieval treble, the technique of diminution and the gradual formation of typical ornaments as a result of "crystallization".

Classification plays an important role in the study of ornaments. Many researchers in their research have given a different classification of ornaments. We would like to bring some of them to your attention. 
The German researcher H. Leichtentritt suggested the existence of four types of ornaments: 1) abbreviated signs for certain sound formulas of an ornamental nature; 2 ) decorations written by the "colourists" in the $16^{\text {th }}$ century, used in diminution; 3) melismas, fioritura for motets, madrigals and cantatas, etc. (considered an important component); 4) improvised decorations, cadences (Leichtentritt, 1908-1909).

C. P. E. Bach in his book "The True Art of Playing Keyboard Instruments" identified three functional groups of melismas: "1) melodic, 2) rhythmic, 3) harmonic" (Bach, 2005). At the same time, several functions of decoration are described here, and combined complex ornaments consisting of two or more simple ornaments are also noted along with simple ornaments.

Erwin R. Jacobi (1967) grouped the ornaments according to a completely different function. E. Jacobi gives them a classification based on similar and related features. Grace notes and trills are the main groups.

The principle of classification of ornaments put forward by A. Yurovskiy is somewhat similar to the principle of E. Jacobi. Thus, A. Yurovskiy also presents ornaments in the form of groups: "1) trill ornamentation. This includes various types of trills and mordents; 2) Portamento ornamentation, such as the grace notes, ties and other melismas; 3 ) gruppetto; 4) aspiration (eagerness) and suspension (removal, storage, and etc.)" (Yurovskiy, 1945).

German researcher $\mathrm{G}$. von Dadelsen in his article gave a peculiar classification of ornaments "Ornaments in our time (Verzierungen, Manieren, Ornamente (in German); Fiorette, Fioriture, Abbelimenti (in Italian); Agrements, Broderies (in French); Graces, Ornaments (in English) are called formula-like decorative ornaments, and ornamentation is called the reproduction of melodic sound through small notes or signs. Depending on whether the decorations relate to the beginning, end, or entire length of a given note, there are initial (anschlagende) decorations (vorshlag, anschlag, Schleifer, mordent, paralltriller, schneller), subsequent (nachschlegende) decorations (ornaments, note following gruppetto), and filling (ausfullende) decorations (trill, gruppetto, tremolo, vibrato). These basic types are sometimes used in various forms, combining with each other, that is, penetrating each other. Ornaments sometimes perform not one note, but two initial functions throughout the chord, and here they resemble dill as a decoration filler.

In the performing arts, there are various types of combined decorations. Complex ornaments consisting of various simple ornaments were considered common and acceptable for instrumental music, in particular, music of the $18^{\text {th }}$ century.

Usually at that time, speaking in a manner, fioritura, agreements, ornaments meant an important and additional function. Here ornaments were distinguished as "significant" ("wesentliche - a sign or an element with special signs), and "arbitrary" ("willkürlichte", that is, free ornamentation). It was not until the second half of the eighteenth century in Germany that the term "significant manner" began to be replaced by the term "ornamentation" (Verzierungen), which was used in conjunction with the concept of "ornament".

In addition to the main group of ornamentation, there were other types of decorations that had other features, calling them "special manner" (gewisse Manieren). These include Inegalita ("uneven"), Lombard rhythm, tremolo, vibrato on strings and 
wind instruments, Bebung on the clavichord ("oscillation"), and etc. (Dadelsen, 1966, p. 1527).

Trying to determine the types of ornaments, it is also necessary to refer to the Great Soviet Encyclopaedia. The following types of ornaments are specified there: "1) melismas and 2) free (arbitrary) ornamentation" ("Ornamentika", 1955).

Melismas are small melodic ornaments in terms of form. These include gruppetto, mordent, flams, trill, and etc., and are given as small notes or hints.

Free ornamentation plays melodic sounds through harmonious and more complex passages. They are often marked with small notes"

It seems that the concepts are close to each other, although they are different.

Sometimes it is necessary to abandon the term "melisma" in order to clarify the terminology. In modern music, the term "melisma" is used in another sense, that is, in the sense of decoration. However, this term was applied to works in the $16^{\text {th }}-17^{\text {th }}$ centuries. This style was called "a stilus melismaticus" and was called a simple, embellished singing style. In the Middle Ages, "manner" meant decoration. The structure of the playing style of that period mainly on ornaments is the basis of its naming as manner.

It is also worth noting the invaluable role that ornamentation plays in musical architecture. Ornamentation appears in music as one of the formative factors of creativity: it can be evaluated in two ways:1) as an element that creates a texture; 2) as a type of musical texture.

Musical texture is a form of embodiment of musical material. Musical texture results from the fusion of melodies, harmony, and rhythm, which are the main musical components. Ornamental texture in music is one of the most common types of texture. There are four types of ornamental texture:

1) harmonious

2) melodic

3) melodic and harmonious

4) rhythmic

At the same time, various reference and transition sounds, melodic and rhythmic figuration, non-chordal sounds, and so on are to be noted.

The ornamentation of the melody further complicates its structure. In this respect, its own layers (levels) of melody are formed and each layer is complicated by figurations and other means of expression. As a result of complexity, each layer is enriched within itself. Aranovskiy divides the melody into two layers: 1) the main layer and 2) the ornamented layer.

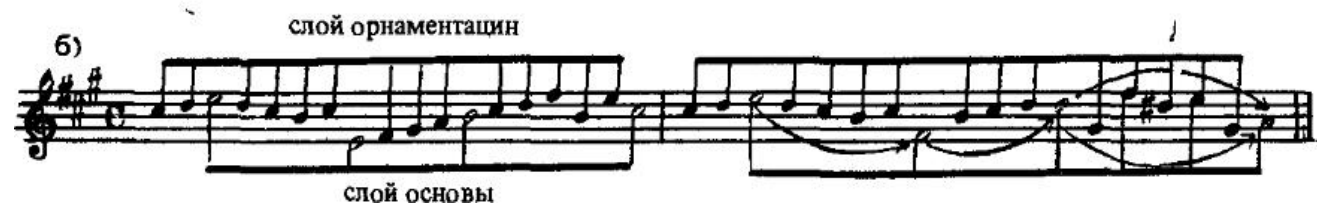

Thus, it is possible to estimate the ornamentation in several aspects:

1) as an aesthetic factor 
2) form as an auxiliary factor

3) timbre as a creative factor

4) artistic content as a creative factor

5) as the main factor in the construction of a melody (melodic figuring)

6) rhythm as a creative factor (rhythmic figure)

7) articulation as a creative factor

8) barcode as an auxiliary factor

Talking about the aesthetic factor, it is necessary to take into account the cyclic factor. In other words, the ornamentation used in works written in the Baroque and Classical periods will correspond to different aesthetic values. We can note this if we compare, for example, any work of F. Couperin for keyboard and the piano sonatas of L. V. Beethoven.

And as a creative factor of the form, we can note the fact that the work has a completely ornamental texture. That is, here rhythmic or harmonic figures can create the form of a work.

Ornamentation can also be regarded as a creative factor of timbre. Using ornamentation, you can obtain any colouration or interpretation (i. e. imitation) (L. Daquin "Le Coucou", K. Debussy "Undine"). At this time, the ornamentation can again act as a layer or create a particular influence, decorating the melody.

As it can be seen, the basis of any musical work is melody, harmony and rhythm. The ornamentation of the same, playing here the role of a constructive component that may manifest itself in various forms.

Ornamentation has the following features:

1) it always applies to any tone.

2) decorations are linked to each other by the main tone, although they are linked to a musical expression or motif.

3 ) each main tone has four auxiliary tones.

4) the main tone can be repeated.

Decorations can be fixed with notes or marked with special signs.

All the various decorative means of decoration can be divided into four main classes.

1) rhythmic (Tremolo, ancient style) -

2) melodic

3) harmonious

4) rhythmic or harmonious

While studying ornamentation in Western European clavier music, we would like to mention the style of performance here. "Style refers to the features inherent in any school, era, or composer" (Williams \& Ledbetter, n.d.). As in keyboard performance, depending on the region to which the ornamentation belongs, the keyboard school has its own stylistic features. These differences primarily coincide with the Baroque era, in which keyboard schools and performing styles were formed. In the following centuries, singing styles mixed and disappeared. As an example, already in the classical era, ornamentation lost its main function, as well as in the Baroque era. "The music changed depending on the time and place, as well as on what instrument you used" (Sadie, 1990, p. 409). 
The use of ornamentation in keyboard music was an aesthetic requirement of the era, rather than a technical flaw of the instrument, as mentioned above. It is wrong to evaluate a piano as an instrument improved on the harpsichord or clavichord, whose technical capabilities are superior to it. Naturally, these instruments were considered related to each other and met the requirements of advanced performance of the era. The improvement of instruments was primarily associated with changes in the aesthetic requirements of the era, the formation of a new worldview. In this regard, it was no longer possible to implement these ideas in the harpsichord and clavichord. "But the unique sound properties of the clavecin (harpsichord), clavichord or instruments of such a type and the special principles of their performance are the embodiment of a certain artistic thought of the $18^{\text {th }}$ century. And it is not because the piano needed further improvement of its predecessors, but because the new performing experience imposed other requirements for the instrument" (Druskin, 1960, p. 27).

While studying the concept of style in ornamentation, you should take into account the parallel keyboard performance and periodicity. The features inherent in keyboard singing and the epoch are the conditions that determine the features of the historical development of ornamentation. These two concepts interact with each other. In the $18^{\text {th }}$ century, the small number of possibilities for the sound of a harpsichord instrument created favourable conditions for the development of ornaments of that time, and ornamentation became a means of overcoming this disadvantage. "The sounds on the harpsichord instrument break, and the sound is not readable or elastic. To cover this disadvantage, French harpsichordists decorated their exquisite melodies with ornaments, trills, flames, vaults, and other devices" (Genike, 1896, p. 50). And taking into account the fact that in the $17^{\text {th }}$ and $18^{\text {th }}$ centuries in European keyboard art in different regions completely different styles were formed, so the decorations changed in the manner of performance. In this regard, speaking about the styles of ornamentation in European keyboard music, two styles should be noted: 1) The French style and 2) The Italian style.

The differences between styles were felt even more sharply in the 17th century: spontaneously, the Italians, who stood out for their emotionality, and the French with a cold, reserved, sharp thinking. It was as if the Italian and French styles took two opposite sides, antagonistic poles, different musical idioms. French musicians opposed free ornaments in Italian music, and they simply did not understand this music. Even musicians of the time noted: "This is not to the taste of J. B. Lully, messenger of beauty and truth. J. B. Lully kicked out a violinist who "spoiled" his concert with various figures that were not characteristic of harmony. Why don't they perform the music properly?" (Harnoncourt, 2009, p. 72). "From all of the above, we can conclude that the musical style includes several features inherent in any composer, any direction, a particular national school, and, in addition, a specific historical period" (Mikhailov, 1965, p. 18).

Ornamentation also has characteristic features of each style. Since opera and concertos were considered the main genres in Italian music, Italian musicians tried to apply the subtleties of Italian vocal art not only in keyboard music but also in instrumental music in general. Free ornaments of fioritura, passage etc. are used in the vocal art. These are characteristic features of Italian piano art. 
When we study French piano music, we encounter a completely different style of thinking. So, the main characteristic features of the French musical style are the clear form and compact nature of the work. The famous French musician, theorist, one of the founders of the National Library of France, Sebastian de Brossard, in his dictionary of music, written by him in 1703, noted: "There is some expressiveness, charm in the works of the Italian style, and the works of the French style are natural, fluid, elegant". Regarding adagio parts of works, especially repetitive parts, the Italians applied the principle of free decoration, as a rule, freely. The richness of the performer's imagination was important there.

In French music, it was considered excessive and forbidden. The French style did not accept free ornamentation either. In the French style, the musicians used codified complex melismas. They even required performers to use embellishments very delicately if necessary. French musicians tried to regulate the decorations and determine the correct place of their use in the work. Every French composer paid great attention to the details of the musical text, including the execution of embellishments. Proper compliance with these records placed a requirement on the performer. "Even though I explain the embellishments, I'm surprised that some musicians don't perform the embellishments correctly in my pieces. Their meanings were described in the book "The True Art of Playing Keyboard Instruments". These mistakes are unforgiving. No one has the right to change the decorations provided by the author. I demand that my works be performed accurately. If the performers did not follow all my recordings with accuracy without any changes, the pieces would not have made an impression on the audience" (Couperin, 1937, p. 10).

\section{Conclusions}

While studying the stylistic qualities of the ornaments of Western European keyboard music, the following conclusion may be made from the above.

Ornamentation of the French style in keyboard performance covers a clear system of signs, clear designation and explanation of signs in musical texts, a regulated system of embellishments.

The main indicators of Italian ornamentation in keyboard music are the use of free ornamentation used in vocal music, the abundance of ornaments and the granting of freedom to the performer.

One of the important aspects that distinguish and characterize the styles of ornamentation in Western music for keyboard, was a requirement to decorate in the French style was performed through the previous notes, and in the Italian style for notes, which includes embellishments. Speaking about the main characteristic qualities of stylistic features of ornaments in Western European keyboard music, A. Yurovskiy (1945) gave the following explanation in an article written for the collection of works by C. P. E. Bach for keyboard "The use of ornamentation as a means of expression is associated "Lombard style" (Lombarda) with propaganda in Europe in the $17^{\text {th }}$ and $18^{\text {th }}$ centuries, and "French style" vice versa. The French performed a rhythmic figure in accordance with the rhythm of the iambic, and the Italians - in accordance with the rhythm of the trochee, the metrical size of the poem. At the same time, we can define two ways of per- 
forming ornamentation: 1) anti-invasive; and 2) subtraction. Thus, in the French style of performance, anticipation, that is, embellishments, according to preliminary estimates, were performed at the expense of the size of the preceding note. And in the Lombard manner, embellishments were performed in a suspension, that is, due to the main musical size.

Most of the ornamental tables known to us before the end of the $17^{\text {th }}$ century are made in the French style and are presented only in some rare cases in the Italian style. But later, that is, starting from the $18^{\text {th }}$ century, at the time when the systematization of French decorations was completed, the subtraction completely eliminated anticipation.

So, from all the above, in Western European keyboard music, the peculiarities of the style in ornamentation can be traced in the $17^{\text {th }}$ and $18^{\text {th }}$ centuries. But later the concept of style in decorations disappeared. This classicism replaced the Baroque era, and at this time embellishments were already regulated and the general system of decorations was adopted in European c keyboard music.

\section{References}

Bach, C. P. E. (2005). Opyt Istinnogo Iskusstva Klavirnoy Igry [Experience of the True Art of Keyboard Performance] (E. Yushcshkevich, Trans.). Early Music [in Russian].

Beyschlag, A. (1978). Ornamentika v Muzyke [Ornamentation in Music] (Z. Vizel, Trans.). Muzyka [in Russian].

Couperin, F. (1937). Izbrannye P'esy dlya Klavesina [Selected Pieces for Clavecine] (0. A. SerovaKhortik, Trans.). Muzyka [in Russian].

Dadelsen, G. von. (1966). Verzierungen [Ornaments]. In Musik in Gesichte und Gegenwart (Vol. 13, pp. 1526-1527). Bärenreiter-Verlag [in German].

Druskin, M. (1960). Klavirnaya Muzyka Ispanii, Anglii, Niderlandov, Frantsii, Italii, Germanii XVIXVIII Vekov [Keyboard Music of Spain, England, the Netherlands, France, Italy, Germany of the XVI-XVIII Centuries]. Gosmuzizdat [in Russian].

Genike, R. (1896). Istoriya Fortepiano v Svyazi s Istoriey Fortepiannoy Virtuoznosti i Literatury [The History of the Piano in Connection with the History of Piano Virtuosity and Literature] (Pt. 1). P. Yurgenson [in Russian].

Harnoncourt, N. (2009). Muzyka Yazykom Zvukov: Put' k Novomu Ponimaniyu Muzyki [Music by the Language of Sounds: The Path to a New Understanding of Music] (I. Prikhod'ko, Trans.). N.p. [in Russian].

Jacobi, E. (1967). Verzierungen [Ornaments]. In Riemann Musik Lexikon. B. Schott's Sohne [in German].

Leichtentritt, H. (1908-1909). Zur Verzierungslehre [To the Ornament Doctrine]. In Sammelbände der Internationalen Musikgesellschaft [Edited Volumes of the International Music Society] (Vol. 10, pp. 613-633). Breitkopf \& Hartell [in German].

Mikhailov, M. K. (1965). O Ponyatii Stilya v Muzyke [Regarding the Concept of Style in Music]. Voprosy Teorii i Estetiki Muzyki, 4, 16-28 [in Russian].

Neumann, F. (1988). Interpretation Problems of Ornament Symbols and Two Recent Case Histories: Hans Klotz on Bach, Faye Fergusonon Mozart. Performance Practice Review, 1(1), Article 7. https://doi.org/10.5642/perfpr.198801.01.7. 
Ornamentika [Ornamentation]. (1955). In Bol'shaya Sovetskaya Entsiklopediya [Great Soviet Encyclopedia] (Vol. 31, pp. 216-217). Bol'shaya Sovetskaya Entsiklopediya [in Russian]. Sadie, J. A. (Ed.). (1990). Companion to Baroque Music. University of California Press. Williams, P., \& Ledbetter, D. (n.d.). Continuo [basso continuo]. In Grove Music Online. https://doi. org/10.1093/gmo/9781561592630.article.06353.

Yurovskiy, A. (1945). Frantsuzskaya Muzykal'naya Ornamentika [French Musical Ornamentation] [Doctoral Dissertation]. Moscow [in Russian].

\section{ІСТОРІЯ РОЗВИТКУ ОРНАМЕНТИКИ В МУЗИЦІ, ПРИНЦИПИ Ії ФОРМУВАННЯ ТА СТИЛЬ ВИКОНАННЯ}

\section{Гюнель Бакірова}

докторант; ORCID: 0000-0001-8536-2139; e-mail: gunnel.bakirova.88@mail.ru

Бакинська музична академія імені Узеіра Гаджибейлі, Баку, Азербайджан

\section{Анотація}

У статті досліджується історія розвитку орнаментики в клавірній музиці, принципи її формування та стилі виконання. Попри те, що орнаментика зазнавала різноманітних змін за змістом залежно від періоду, вона є одним з основних засобів вираження клавірної музики. Орнаментика проявляється в різних формах та є не тільки прикладом прикраси, а й виступає в ролі основного компонента в створенні твору. Також прикраси мають істотну вагу як естетичний чинник.

Мета дослідження полягає в розгляді принципу історичного розвитку орнаментики, класифікуванні її видів та визначенні ролі в музиці. Водночас, в рамках проведеного дослідження, вноситься ясність в поняття про стиль орнаментики в клавірній музиці Західної Європи.

Методологія дослідження базується на комплексному музично-аналітичному, теоретичному та історичному аналізі, узагальненні наукової літератури музикознавців Західної Європи й Росії на тему орнаментики.

Наукова новизна дослідження. Вперше, в рамках музикознавства Азербайджану, досліджено особливості, принципи виконання орнаментики в західноєвропейській клавірній музиці.

Висновки. Орнаментика має важливе значення для клавірної музики Західної Європи і виступає в ролі її основного засобу вираження. ІІї розвиток в клавірній музиці безпосередньо пов'язаний з мистецтвом імпровізації, в якому прикраси вважаються головним засобом вираження. Орнаментика $є$ не тільки прикрасою мелодії - поряд зі структурою вона відіграє важливу роль для створення ритмічної будови твору, художнього змісту твору, форми та фактури. Музикознавці розглядали орнаментику у різних аспектах і класифікували їі в різноманітних формах. У сучасний період орнаментика підрозділяється на дві групи: у вигляді прикрас і вільна орнаментика.

Однією з основних особливостей клавірної музики Західної Європи $є$ те, що вона відображає в собі музичні традиції того періоду. Відзначимо, що орнаментика в клавірній 
музиці пройшла етап свого високого розвитку в епоху Бароко. Основною характерною особливістю тут виступає відсутність регламентації орнаментики, її зміна залежить від школи, стилю виконання. Але пізніше поняття стилю в прикрасах було втрачено. Так, в епоху Класицизму прикраси вже регламентувалися і була прийнята загальна система прикрас в європейській клавірній музиці.

Ключові слова: орнаментика; Бароко; клавірна музика; стиль; фортепіано; прикраса; виконання

\section{ИСТОРИЯ РАЗВИТИЯ ОРНАМЕНТИКИ В МУЗЫКЕ, ПРИНЦИПЫ ЕЕ ФОРМИРОВАНИЯ И СТИЛЬ ИСПОЛНЕНИЯ}

\section{Гюнель Бакирова}

докторант; ORCID: 0000-0001-8536-2139; e-mail: gunnel.bakirova.88@mail.ru

Бакинская музыкальная академия имени Узеира Гаджибейли, Баку, Азербайджан

\section{Аннотация}

В статье исследуется история развития орнаментики в клавирной музыке, принципы ее формирования и стили исполнения. Несмотря на то, что орнаментика подвергалась различным изменениям по содержанию в зависимости от периода, она является одним из крупнейших средств выражения клавирной музыки. Орнаментика проявляется в различных формах и является не только образцом украшения, но и выступает в роли основного компонента в создании произведения. Также украшения имеют существенную важность в качестве эстетического фактора.

Цель исследования заключается в рассмотрении принципа исторического развития орнаментики, классифицировании ее видов и определении роли в музыке. В то же время, в рамках проведенного исследования вносится ясность в понятие о стиле орнаментики в клавирной музыке Западной Европы.

Методология исследования базируется на комплексном музыкально-аналитическом, теоретическом и историческом анализе, обобщении научной литературы музыковедов Западной Европы и России на тему орнаментики.

Научная новизна исследования. Впервые в рамках музыкальной науки Азербайджана исследованы особенности, принципы исполнения орнаментики в западноевропейской клавирной музыке.

Выводы. Орнаментика имеет важное значение для клавирной музыки Западной Европы и выступает в роли ее основного средства выражения. Ее развитие в клавирной музыке напрямую связано с искусством импровизации, в котором украшения считаются главным средством выражения. Орнаментика является не только украшением мелодии - наряду со структурой она играет важную роль для создания ритмического строения произведения, художественного содержания произведения, формы фактуры. Музыковеды рассматривали орнаментику с точки зрения различных призм и классифицировали ее в различных формах. В современный период орнаментика подразделяется на две группы: в виде украшений и свободная орнаментика. 
Одной из основных особенностей клавирной музыки Западной Европы является то, что она отражает в себе музыкальные традиции того периода. Отметим, что орнаментика в клавирной музыке прошла этап своего высокого развития в эпоху Барокко. Основной характерной особенностью здесь выступает отсутствие регламентации орнаментики, ее изменение в зависимости от школы, стиля исполнения. Но позже понятие стиля в украшениях было утрачено. Так, в эпоху Классицизма украшения уже регламентировались и была принята общая система украшений в европейской клавирной музыке.

Ключевые слова: орнаментика; Барокко; клавирная музыка; стиль; фортепиано; украшение; исполнение 